\title{
A Test Of The M\&M Capital Structure Theories
}

Richard H. Fosberg, William Paterson University, USA

\begin{abstract}
Modigliani and Miller $(1958,1963)$ predict two very specific relationships between firm value and the amount of debt in the firm's capital structure, depending on whether or not the firm pays corporate income taxes. Although there has been some testing of the implications of these equations, I have been unable to find anyone who has tested them in the exact forms specified by MM. In this paper, the MM equations are tested exactly as specified. The results of these tests indicate that neither the MM tax nor the no-tax valuation equations are accurate predictors of firm value. Specifically, the value of the unlevered firm accounts for much less of firm value than predicted and the sign of the coefficient of the interest tax shield variable is negative, instead of positive as MM predict. These results are robust to the inclusion of control variables for firm growth, earnings variability, and the existence of other tax shields.
\end{abstract}

Keywords: Capital Structure, Debt, Firm Value

\section{INTRODUCTION}

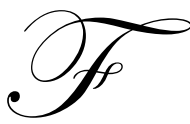

ifty years ago Modigliani and Miller $(1958,1963)$ laid the foundation of the modern capital structure theory. Specifically, Modigliani and Miller (henceforth MM) showed that in perfect and frictionless capital markets, where firms could issue riskless debt, firm capital structure was irrelevant. That is, the amount of debt in the firm's capital structure did not affect the value of the firm and, therefore, firms did not have an optimal capital structure. In terms of an equation, MM showed that

$\mathrm{V}_{\mathrm{L}}=\mathrm{V}_{\mathrm{U}}$

the value of a levered firm $\left(V_{L}\right)$ is equal to the value of the unlevered firm $\left(V_{U}\right)$, where the unlevered firm is the same firm with no debt in its capital structure. In this case, shifting a firm's capital structure only shifts the cash flows that a firm generates between debt and equity holders without affecting total firm value. When MM allowed for the existence of corporate income taxes, they got a completely different result. They showed that in this case, capital structure did matter and that the value of the firm was an increasing function of the amount of debt in the firm's capital structure. The exact relationship was shown to be

$\mathrm{V}_{\mathrm{L}}=\mathrm{V}_{\mathrm{U}}+\mathrm{tD}$

where $\mathrm{D}$ is the value of the firm's debt outstanding and $t$ is the firm's average corporate income tax rate. The tD term in equation 2 measures the present value of the corporate income tax savings generated by the interest paid on the firm's debt (the interest tax shield). In MM with taxes, firm value increases as the amount of debt in the firm's capital increases and all firms have an optimal capital structure that is $99.9 \%$ debt.

A number of authors have attempted to test the validity of the MM theories with most of the tests concerned with testing equation 2 as corporate income taxes are a part of the modern business environment. The results of these tests have been inconsistent. For example, several studies (e.g. Friend and Lang (1988)) found that the amount of debt in the firm's capital is inversely related to firm profitability and the variability in firm profitability. The former result is inconsistent with $\mathrm{MM}$ as normally the more profitable the firm is, the more debt financing the firm should employ in order to maximize the value of the interest tax shield. The latter result is 
consistent with MM as the greater a firm's profit variability, the less valuable the interest tax shield generated by the firm's debt and the smaller the amount of debt the firm should employ in its capital structure. In a non-traditional approach, Graham (2000) attempts to quantify the tax benefits of debt financing by integrating the firm's tax function over the amount of the firm's interest expense. He finds that the interest tax shield accounts for, on average, $9.7 \%$ of the market value of his sample firms. Using the last term on the right-hand side of equation $2(\mathrm{tD})$, he estimates that the value of the interest tax shield is $13.2 \%$ of firm value. The difference in the two estimates of the value of the interest tax shield implies that MM may be overestimating the value of the interest tax shield. Fama and French (1998) test for the effect of debt in the firm's capital structure on firm value using a regression analysis. In their regressions, firm value is regressed on a number of control variables one of which one is the firm's interest payments. Fama and French find that the coefficient on the interest expense variable has a negative sign, which contradicts the prediction of MM's equation 2.

\section{METHODOLOGY AND SAMPLE SELECTION}

One possible criticism of the above studies is that none of them has tested MM's theories in the exact form specified by MM (equations 1 and 2). The objective of this study is to address this situation by testing MM equations 1 and 2 exactly as specified. The first step in this process is to quantify MM's calculation of $V_{U}$ for the sample firms. MM specify that $V_{U}=X(1-t) / R_{U}$ where $X$ is expected operating profits before interest and taxes and $\mathrm{R}_{\mathrm{U}}$ is investor's required return for investing in the equity of the firm if the firm had no debt in its capital structured (an unlevered firm). $X(1-t)$ is essentially the firm's expected after-tax operating cash flow to the shareholders of the unlevered firm. The difficulty with estimating $\mathrm{R}_{\mathrm{U}}$ for sample firms is that most firms have some debt in their capital structure and therefore, $R_{U}$ is not readily observable. Use of the CAPM equation and the formula for the beta of a levered firm's common stock will allow for the avoidance of this problem and the estimation of $\mathrm{R}_{\mathrm{U}}$. Using the CAPM, then $R_{U}=R_{F}+\left(R_{M}-R_{F}\right) \beta_{U}$ where $R_{F}$ is the risk-free rate of return (estimated using the average return on one year t-bills), $\mathrm{R}_{\mathrm{M}}$ is the expected return on the market portfolio (estimated using the average return on the $\mathrm{S} \& \mathrm{P}$ 500 portfolio). The beta of the unlevered firm $\left(\beta_{\mathrm{U}}\right)$ is estimated by solving the levered beta formula

$\beta_{\mathrm{L}}=\beta_{\mathrm{U}}(1+(1-\mathrm{t}) \mathrm{D} / \mathrm{E})$

for $\beta_{\mathrm{U}}$, yielding

$\beta_{\mathrm{U}}=\beta_{\mathrm{L}} /(1+(1-\mathrm{t}) \mathrm{D} / \mathrm{E})$

where $\mathrm{D}$ is the value of the firm's debt and $\mathrm{E}$ is the value of the firm's common equity. Estimates of $\beta_{\mathrm{U}}$ are calculated using estimates of $\beta_{\mathrm{L}}$, D (book value of long-term debt) and $\mathrm{E}$ (market capitalization) obtained from COMPUSTAT. As explained below, $\mathrm{t}$ is assumed to be $35 \%$. All other data used in this study also comes from COMPUSTAT. In the regression analysis to follow two variables will be used to capture the effect of the interest tax shield on firm value. In some regressions $\mathrm{tD}$ will be used to measure the effect of the interest tax shield and in others the firm's interest expense (I) will be employed. MM show that $\mathrm{tD}=\mathrm{trD} / \mathrm{r}=\mathrm{tI} / \mathrm{r}$ where $\mathrm{r}$ is the rate of interest on the firm's debt, therefore, using I to measure the interest tax shield is equivalent to using tD. The only difference is the predicted values of the coefficients on the variables. If $\mathrm{tD}$ is used in the regressions the predicted coefficient is one while if I is used the predicted coefficient is $t / r$.

In each sample year from 1998 to 2007, selected from COMPUSTAT were all firms for which sufficient data could be obtained to perform the empirical tests that are used in this study. To reduce the effect of outliers on the empirical results, firms with an estimated $\mathrm{V}_{\mathrm{U}}<0$, or an estimated $\beta_{\mathrm{U}}$ greater than 1.8 or less than .2 , or a negative book value of common equity were eliminated from the sample. This left a total of 18,539 firm/years of data with an average sample size of 1,854 firms per year. Table 1 contains the means of selected variables for the sample firms for years 1998 and 2007. The mean total assets of the sample firms increased significantly over the sample period from \$3,458 million in 1998 to \$9,573 million in 2007.

The sample firm's mean total debt to total assets ratio (Debt Ratio), however, remained fairly stable over the sample time period (.241 in 1998 vs. .230 in 2007). The operating cash flow to common shareholders assuming the firm was unlevered (Cash Flow) increased from $\$ 383$ million in 1998 to $\$ 1,101$ million in 2007. Cash Flow is 
calculated by subtracting income taxes from EBIT and then subtracting .35 times the interest expense from the net. The last calculation is included to adjust for the additional income taxes the firm would have paid if the firm was unlevered. This calculation is based on the assumption that the firm's average tax rate is $35 \%$. Since corporate taxable income over $\$ 75,000$ is taxed at marginal rates of between $34 \%$ and $39 \%$ an assumed $35 \%$ average tax rate should be reasonable for most firms. Average interest expense (Interest) has more than doubled over the sample period from $\$ 68.9$ million in 1998 to $\$ 144$ million in 2007 . The present value of the interest tax shield generated by the firm's debt (PVITS) also more than doubled over the sample period from $\$ 370$ million is 1998 to $\$ 904$ million in 2007. In the MM tax model PVITS equals tD. To estimate this for our sample firms we use the book value of total debt to proxy for $\mathrm{D}$ and assume a $35 \%$ average tax rate for each sample firm.

Table 1: Means of Selected Variables

\begin{tabular}{lcc}
\hline & $\mathbf{1 9 9 8}$ & $\mathbf{2 0 0 7}$ \\
\hline Total Assets & $3,548 \mathrm{~m}$ & $9,573 \mathrm{~m}$ \\
Debt Ratio & .241 & .230 \\
Cash Flow & $383 \mathrm{~m}$ & $1,101 \mathrm{~m}$ \\
Interest & $68.9 \mathrm{~m}$ & $144 \mathrm{~m}$ \\
PVITS & $370 \mathrm{~m}$ & $904 \mathrm{~m}$ \\
\hline
\end{tabular}

$\mathrm{m}=$ million

\section{EMPIRICAL TESTS}

To test MM equations 1 and 2, we will use a series of regressions in which the value of the levered firm $\left(\mathrm{V}_{\mathrm{L}}\right)$ is regressed on various $\mathrm{MM}$ and control variables. The value of a sample firm is estimated as total assets minus book value of common equity plus market value of common equity. In this study, data from all of the sample years is pooled to create one data set that is used in all regressions. To reduce the effects of heteroskedasticity on our analysis all variables used in the regressions are scaled by firm total assets and all test statistics are calculated using White's heteroskedasticity adjusted standard errors. Additionally, a fixed effects regression model is used to account for any calendar year effects on the sample data. Table 2 contains three regressions that employ MM variables only. In all regressions, the $t$ values of the regression coefficients are in parentheses below the regression coefficients. In the first regression, equation 1 (MM without taxes) is estimated using $\mathrm{V}_{\mathrm{u}}$ as the sole explanatory variable. If equation 1 is the correct specification of firm value the intercept in the regression should be zero and the coefficient on $\mathrm{V}_{\mathrm{u}}$ should be one. Inspection of the estimated coefficients reveals that neither of those conditions occurs.

The intercept is highly significant and while the coefficient of $\mathrm{V}_{\mathrm{u}}$ is positive and significant at the $1 \%$ level but its value of .366 is far below one. These results, along with the low $\mathrm{R}^{2}$ for the regression (.04), suggest that there are other variables besides $\mathrm{V}_{\mathrm{u}}$ that affect firm value. To investigate this, we next estimate equation 2 using two different specifications of the last term in that equation. In the second regression in Table 2 our estimate of tD, the present value of the firm's interest tax shield (PVITS), is used as a second explanatory variable. Adding PVITS to the regression has little effect on the coefficient of $\mathrm{V}_{\mathrm{u}}$ but raises the $\mathrm{R}^{2}$ to .1. The coefficient of PVITS is significant at the $1 \%$ level but, contrary to MM's equation 2, has a negative sign. In an alternate specification, the firm's interest payment (Interest), is used to proxy for the interest tax shield. When Interest is used as the second explanatory variable in a test of equation 2 its coefficient should be $t / r$. Assuming a 35\% average tax rate and a $7 \%$ interest rate on the firm's debt then the coefficient of Interest should be approximately five. In the last regression, neither the sign nor the magnitude of the coefficient (-28.0) is as predicted by MM even though it is significant at the $1 \%$ level.

The results of the last two regressions are consistent with Fama and French, who found an inverse relationship between a firm's interest expense and firm value. Henceforth, Interest will be used as the interest tax shield proxy in all regressions since its value can be observed and, therefore, does not have to be estimated as the value of $\mathrm{tD}$ does. 
Since neither MM equation seems to adequately explain the variables that affect firm value, a second set of regressions is estimated using control variables suggested by other authors. The results of these regressions are contained in Table 3. In MM's models, it is assumed that firms have no growth prospects, which clearly is not the case for most firms. To account for the effects of firm growth prospects on firm value, research and development, expenditures $(\mathrm{R} \& \mathrm{D})$ are included as a control variable in the first regression. The presumption is that higher R\&D expenditures will lead to a higher future growth rate in the firm's operating cash flows. As higher growth prospects imply greater firm value, it is anticipated that the sign on this variable will be positive. The coefficient estimate is in fact positive and significant at the $1 \%$ level. However, the inclusion of this explanatory variable had little effect on the coefficient of Interest. Another factor that could affect firm value and the coefficient of Interest is the variability in firm operating cash flows. Generally, greater variability in firm operating cash flows would lower the value of $\mathrm{V}_{\mathrm{U}}$ and the firm's interest tax shield. To check this, the standard deviation in EBIT over the previous eight years $(\sigma)$ is used as a control variable in the second regression. The coefficient of $\sigma$ should have a negative sign. Contrary to expectations, the coefficient has a positive sign and is significant at the $1 \%$ level. Additionally, the inclusion of $\sigma$ in the regression did not have a material effect on the coefficients of the other explanatory variables.

Table 2: M\&M Variables Only

\begin{tabular}{|c|c|c|c|}
\hline Dependent Variable: & $\mathbf{V}_{\mathrm{L}}$ & $\mathbf{V}_{\mathrm{L}}$ & $\mathbf{V}_{\mathrm{L}}$ \\
\hline Intercept & $\begin{array}{c}1.34 \mathrm{c} \\
(30.0)\end{array}$ & $\begin{array}{c}1.88 \mathrm{c} \\
(40.3)\end{array}$ & $\begin{array}{c}1.74 \mathrm{c} \\
(36.7)\end{array}$ \\
\hline $\mathrm{V}_{\mathrm{u}}$ & $\begin{array}{l}.366 \mathrm{c} \\
(17.1)\end{array}$ & $\begin{array}{l}.389 \mathrm{c} \\
(18.0)\end{array}$ & $\begin{array}{l}.426 \mathrm{c} \\
(18.9)\end{array}$ \\
\hline PVITS & - & $\begin{array}{l}-6.86 c \\
(28.3)\end{array}$ & - \\
\hline Interest & - & - & $\begin{array}{l}-28.0 \mathrm{c} \\
(23.8)\end{array}$ \\
\hline Fixed Effects & Yes & Yes & Yes \\
\hline $\operatorname{Adj} R^{2}$ & .04 & .10 & .09 \\
\hline $\mathrm{N}$ & 18,539 & 18,539 & 18,539 \\
\hline
\end{tabular}

$\mathrm{a}=$ significant at the $10 \%$ level

$\mathrm{b}=$ significant at the $5 \%$ level

$\mathrm{c}=$ significant at the $1 \%$ level

DeAngelo and Masulis (1980) show that other variables, like depreciation expense and tax loss carry forwards, can produce valuable tax shields similar to the interest tax shield. If a firm has sufficient earnings to take advantage of these other tax shields then they should increase firm value and have positive coefficients when included as control variables in the MM regressions. These other tax shields may also reduce the value of the interest tax shield if firm earnings are not high enough to take advantage of the full tax shield offered by the firm's interest payments. Consequently, the inclusion of proxies for these other tax shields in the regressions may affect the coefficient of Interest. To test this possibility two more regressions are run using depreciation expense (Depr) and tax loss carry forwards (Tax Loss) as control variables. The coefficient of Depr in the third regression is negative and significant at the $1 \%$ while the coefficients of $\mathrm{V}_{\mathrm{U}}$ and Interest are little changed. In the fourth regression, the coefficient of Tax Loss is positive and significant at the $1 \%$ level, again with no material effect on the coefficients of $\mathrm{V}_{\mathrm{U}}$ or Interest. In the last regression, all the explanatory variables are included in one regression. This increases the $\mathrm{R}^{2}$ to .22 and causes the coefficient of Tax Loss to become statistically insignificant but otherwise leaves the results little changed. 
Table 3: M\&M with Control Variables

\begin{tabular}{|c|c|c|c|c|c|}
\hline Dependent Variable: & $\mathbf{V}_{\mathrm{L}}$ & $\mathbf{V}_{\mathbf{L}}$ & $\mathbf{V}_{\mathbf{L}}$ & $\mathbf{V}_{\mathbf{L}}$ & $\mathbf{V}_{\mathbf{L}}$ \\
\hline Intercept & $\begin{array}{l}1.48 \mathrm{c} \\
(29.4)\end{array}$ & $\begin{array}{c}1.67 \mathrm{c} \\
(33.6)\end{array}$ & $\begin{array}{l}1.87 \mathrm{c} \\
(38.1)\end{array}$ & $\begin{array}{l}1.74 \mathrm{c} \\
(37.0)\end{array}$ & $\begin{array}{l}1.54 \mathrm{c} \\
(30.1)\end{array}$ \\
\hline $\mathrm{V}_{\mathrm{u}}$ & $\begin{array}{l}.416 c \\
(19.4)\end{array}$ & $\begin{array}{l}.408 c \\
(16.7)\end{array}$ & $\begin{array}{l}.523 c \\
(18.2)\end{array}$ & $\begin{array}{c}.421 c \\
(19.6)\end{array}$ & $\begin{array}{l}.503 c \\
(17.3)\end{array}$ \\
\hline Interest & $\begin{array}{l}-22.0 \mathrm{c} \\
(18.9)\end{array}$ & $\begin{array}{l}-26.6 \mathrm{c} \\
(30.9)\end{array}$ & $\begin{array}{l}-27.5 \mathrm{c} \\
(23.8)\end{array}$ & $\begin{array}{c}-28.0 \mathrm{c} \\
(24.0)\end{array}$ & $\begin{array}{l}-20.6 \mathrm{c} \\
(24.4)\end{array}$ \\
\hline$R \& D$ & $\begin{array}{l}8.13 c \\
(12.9)\end{array}$ & - & - & - & $\begin{array}{l}7.89 \mathrm{c} \\
(12.6)\end{array}$ \\
\hline$\sigma$ & - & $\begin{array}{l}1.60 \mathrm{c} \\
(3.02)\end{array}$ & - & - & $\begin{array}{l}.898 \mathrm{a} \\
(1.90)\end{array}$ \\
\hline Depr & - & - & $\begin{array}{l}-6.37 \mathrm{c} \\
(9.72)\end{array}$ & - & $\begin{array}{l}-5.87 \mathrm{c} \\
(9.35)\end{array}$ \\
\hline Tax Loss & - & - & - & $\begin{array}{l}.263 \mathrm{c} \\
(2.81)\end{array}$ & $\begin{array}{l}.030 \\
(0.25)\end{array}$ \\
\hline Fixed Effects & Yes & Yes & Yes & Yes & Yes \\
\hline Adj $R^{2}$ & .14 & .15 & .10 & .10 & .22 \\
\hline $\mathrm{N}$ & 18,539 & 18,539 & 18,539 & 18,539 & 18,539 \\
\hline
\end{tabular}

$\mathrm{a}=$ significant at the $10 \%$ level

$\mathrm{b}=$ significant at the $5 \%$ level

$\mathrm{c}=$ significant at the $1 \%$ level

Since one year's operating cash flow is a somewhat noisy measure of expected operating cash flow, two additional regressions are run in which the 3 year and 5 year average operating cash flow is used to compute $\mathrm{V}_{\mathrm{U}}$. These average operating cash flows should prove a less noisy estimate of expected cash flow and give better estimates of the regression coefficients. The results of these regressions are contained in Table 4. Surprisingly, the coefficients on $\mathrm{V}_{\mathrm{U}}$ in the first regression (computed using the 3 year average) and the second regression (computed using the 5 year average) are significantly reduced in magnitude but still have positive signs and retain their significance levels. No obvious explanation for this result comes to mind. Nevertheless, the coefficient of Interest remains negative in both regressions, but with a somewhat smaller magnitude than in previous regressions.

\section{CONCLUSION}

Modigliani and Miller $(1958,1963)$ predict two very specific relationships between firm value and the amount of debt in the firm's capital structure depending on whether or not the firm pays corporate income taxes. Although there has been some testing of the implications of these equations, I have been unable to find anyone who has tested them in the exact forms specified by MM. In this paper, the MM equations are tested exactly as specified. The results of these tests indicate that neither the MM tax nor the no-tax valuation equations are accurate predictors of firm value. Specifically, the value of the unlevered firm accounts for much less of firm value than predicted and the sign of the coefficient of the interest tax shield variable is negative, instead of positive as MM predict. These results are robust to the inclusion of other control variables for firm growth, earnings variability, and the existence of other tax shields. 
Table 4: M\&M with Adjusted $V_{u}$

\begin{tabular}{lcc}
\hline \multicolumn{1}{c}{ Dependent Variable: } & $\mathbf{V}_{\mathbf{L}}$ & $\mathbf{V}_{\mathbf{L}}$ \\
\hline Intercept & $1.70 \mathrm{c}$ & $(32.6)$ \\
& $(32.0)$ & $.167 \mathrm{c}$ \\
$\mathrm{V}_{\mathrm{u}}$ & $.269 \mathrm{c}$ & $(5.05)$ \\
& $(7.68)$ & $-17.8 \mathrm{c}$ \\
Interest & $-18.4 \mathrm{c}$ & $(19.8)$ \\
& $(20.8)$ & $8.58 \mathrm{c}$ \\
R\&D & $8.45 \mathrm{c}$ & $(12.5)$ \\
& $(12.2)$ & $2.21 \mathrm{c}$ \\
$\sigma$ & $1.95 \mathrm{c}$ & $(3.53)$ \\
& $(3.61)$ & $-1.50 \mathrm{c}$ \\
Depr & $-2.51 \mathrm{c}$ & $(2.64)$ \\
& $(3.76)$ & -.022 \\
Tax Loss & .003 & $(0.17)$ \\
Fixed Effects & $(0.02)$ & Yes \\
\hline
\end{tabular}

$\mathrm{a}=$ significant at the $10 \%$ level

$\mathrm{b}=$ significant at the $5 \%$ level

$\mathrm{c}=$ significant at the $1 \%$ level

\section{AUTHOR INFORMATION}

Richard H. Fosberg is Professor of Finance at William Paterson University in Wayne, NJ. His primary research interest lies in capital structure theory. The author has published numerous articles in scholarly journals including the Journal of Banking and Finance and the Journal of Financial Research.

\section{REFERENCES}

1. DeAngelo, H. and R. Masulis, Optimal Capital Structure Under Corporate and Personal Taxation, Journal of Financial Economics, Vol. 8 (1980), 3-29.

2. Fama, E. and K. French, Taxes, Financing Decisions, and Firm Value, Journal of Finance, Vol. 53 No. 3 (1998), 819-43.

3. Friend, I. and H. Lang, An Empirical Test of the Impact of Managerial Self-Interest on Corporate Capital Structure, Journal of Finance, Vol. 43 No. 2 (1988), 271-81.

4. Graham, John, How Big Are the Tax Benefits of Debt? Journal of Finance, Vol. 55 No. 5 (2000), 19011941.

5. Modigliani, F. and M. Miller, The Cost of Capital, Corporation Finance and The Theory of Investment, American Economic Review, Vol. 48 No. 3 (1958), 261-97.

6. Modigliani, F. and M. Miller, Corporate Income Taxes and the Cost of Capital: A Correction, American Economic Review, Vol. 53 (1963), 433-33. 